\title{
ATHENS AND THE PROCESS OF MIGRATION TO THE MARITIME SPACES OF THE BLACK SEA
}

Maria Regina Candido ${ }^{1}$

\begin{abstract}
Through the maritime geographical space that the Greeks made the process of migration to the different regions bathed by sea throughout the Aegean, Mediterranean and Black Sea, founded new poleis, carried out a shared identity, transferred their cults and gods, produced ceramic and metal artifacts forming the net Of maritime connectivity through emporium and apoikias.
\end{abstract}

Keywords

Connectivity; Geography; Black Sea.

\section{Resumo}

Através do espaço geográfico marítimo que os gregos efetivaram o processo de migração para as diferentes regiões banhadas pelo mar Egeu, Mediterrâneo e Mar Negro, fundaram novas poleis, efetivaram uma identidade compartilhada, transferiram seus cultos e deuses, produziram artefatos de cerâmica e metais formando a rede de conectividade marítima através de emporium e apoikias.

\section{Palavras-chave}

Conectividade; Geografia; Mar Negro.

\footnotetext{
1 Assistant Professor, Rio de Janeiro State University, Rio de Janeiro, Brazil. E-mail: medeiacandido@gmail.com
} 
Reflecting on time, past, present and future has become an essential activity of human societies. The base of the construction of History, in which time has become the object of knowledge, analysis of transformation, permanent rapid changes in which we live, resulting in everything that is solid disintegrates in the air (Guarinello, 2008: 14). In this essay, we propose to bring to the debate the considerations on the maritime geographical spaces of the Mediterranean and the Black Sea in the archaic and classical period of the Greeks. The Maritime area considered as a propelling agent of temporal rhythms of its own, to which we can affirm that it is not the geographical spaces that make history but the men who are masters and inventors of these spaces (Braudel, 1966: 206).

During an extended period in the construction of Western history, the Aegean Sea and Mediterranean allowed contact and interaction between cultures of different ethnicities, spreading beliefs and tradition and has been an object of idealizations for the Western world. The stability of the maritime nature favoured the cabotage trade of different products such as the stones of the Cyclades Islands, the marble of Italy and the Aegean. There is a change of leather of Cyprus and Sardinia, the iron of Iberia, the gold of the region of Thasos and Thrace, the Andalusian silver as well as the cereals of the Tunisian plain, the Po area in Campania, and Sicily. Products and goods that favoured the approach of different cultures, beliefs, and traditions around the Mediterranean, an action that extended to the Black Sea.

Maritime geographical spaces communicate with each other through trade and commerce, but also allow the movement of people. Good things and richness of the Mediterranean and the Black Sea lie precisely in this drive brought about by the intense relationships that have developed, the result of which has materialized in all fields of social, religious, and economic life such as mixed marriages, hybrid culture, new cults and religious rites.

We assume that the society of the Greeks can be thought of concerning near and distant connectivity through the Social Network Theory approach, translated by us as Theory of Social Connectivity. Although the concept of network belongs to the area of technological knowledge, we consider that the notion holds the ability to apply theoretical along with Ancient History. I suppose that the maritime world was interconnected and Greeks sometimes called the Mediterranean and the Black Sea as he hemetera thalassa/our sea, the equivalent Latin term, mare nostrum (Malkin, 2011: 3). This theory has been applied by Ch. Constantakopolou, The Dance of the Islands: Insularity, Networks, Athenian Empire and the 
Aegean World (2007), Irad Malkin and Ch. Constantakopolou, Greek and Roman Network in the Mediterranean (2009) and Irad Malkin. A Small Greek World. Network in the ancient Mediterranean. The authors start from the perspective that maritime connectivity has encouraged the mobilization of Athenians, Greek and non-Greeks by the Mediterranean Sea towards the Black Sea since the archaic period. Through the maritime geographical space that the Greeks effected the process of migration to the different regions bathed by the Aegean, Mediterranean and Black Sea, they founded new poleis, realized a shared identity, transferred their cults and gods, produced ceramic and metal artifacts forming the net of maritime connectivity through emporium, cleuruquias and apoikias.

We argue that the regions bathed by the Mediterranean extended their contacts towards the Near East, Nile Valley, Africa, and Mesopotamia reaching the Black Sea. In these regions, the Greeks established the unipolar leadership that extended to the Romans whose cultural contacts contributed to the formation of Mediterranean civilization, of which we believe we are heirs. We assume that the maritime geographical space of the Mediterranean has a vast historiography, however, the connectivity process of the Greeks in different regions of the ancient world has the peculiarity of being the Black Sea region less known of the academic universe of the West and with lack of analysis, mainly by us, of Latin American historiography.

Purcel said that F. Braudel suggests that over the immense past of mankind, the sea has become its most beautiful testimony and in the book The Mediterranean, he says that the Mediterranean Sea is a unit that goes from Antiquity to Middle Ages. The statement is part of the "Mediterranean paradigm" which considers the sea region as a factor of cultural unity, resulting in the pan-Mediterranean approach. The thesis was refuted in The Corruption Sea whose authors argued that the fragmentation of the landscape of the region, faced with their physical and ethnic diversity, never managed to formulate a cultural unity (Purcell, 2000: 09). Nicholas Purcell states that the region integrates three forms of approaches, namely: the interactionists who analyse the region from physical geography in which the sea becomes a way of contact and communication; the ecologizing that emphasize the relations of man and the environment resulting in the analysis of the established cultural ones in the interior of the region and the third group that unifies the previous two under the approach of the microecology and created the notion of connectivity through the sea (Purcell, 2000: 10).

Greek historians like Thucydides and Herodotus bring in their speech the conceptualization of the sea defined as talassocracia result of the success 
of the Athenian unipolar leadership, established from the Aegean Sea, passing through the Mediterranean and extending to the Black Sea. The commercial and commercial activities in Athens received pecuniary incentives unprecedented in the $\mathrm{V}$ century, promoted by maritime activity in the military and mercantile sense. Herodotus tells us that the strategist Themistocles persuaded each Athenian to renounce his share of the resources of the Laurion mines and to apply two hundred ships for defence of the polis. The historian adds that war had become the salvation of Hellas, for it compelled the Athenians to serve as sailors (Herodotus, VII: 144); Thucydides reported the theme (I: 74) and Plutarch: Themistocles (v. 4) too.

The documentation allows us to affirm that it was the trieres of Themistocles who saved Athens and Greece from failing before the Persians and made them triumph in Salamis. The researchers add that thanks to Pericles 'political actions, the trieres ensured Athens' maritime hegemony and prosperity. The result prompted the emergence of urban sectors that came to press for an active foreign policy representing not only the interest of traders in the market, but a recognition of the validity of the relationship between military remuneration and economic prosperity (Humphys, 1978: 7). Claude Mossé adds that the naval fleet and the creation of the League of Delos by Themistocles and Aristides are defined as the main instruments that propelled the establishment of Athenian imperialism (Mossé, 1993: 33).

Aristotle shows that, like Themistocles, the insertion of the fourth social segment based in urban space became a practice also with Pericles adopting the policy of naval power by inserting the lower classes, assuming more and more leadership in politics (Aristotle, Constitution of Athens, XVII), that is, the citizens of the Athenian fleet in defence of the polis sought their active participation in the administration of public affairs of the polis, thanks to the process of maritime expansion fostered by Athens. The political action of the so-called Athenian empire transcends the structure of the Polish community by building areas of influence in the regions bathed by the Aegean. The establishment of the Delos League and the resources coming from the allies helped in the payment of the misthoi and in the maintenance of the participation of the emerging of the urban sectors in the democracy (Candido, 2016: 115).

Athens recognizes that the expansion of hegemony towards maritime control would only be effective through the establishment of networks of commercial, mercantile and people connectivity. The materiality of the Athenian thalassocracy became perceptible through the attic ceramic vessels that created a unique technical style in the form of attic vessels of 
black figures, bilingual figures and red figures, the result of which boosted the dynamics of trade and mercantile export of Athens to different regions of the Aegean, Mediterranean to the Black Sea. This fact fostered the emergence of the social segment of the olighoi, the emerging or the new rich, involved in the commercial activities of producing attic ceramics and the merchants responsible for the export of attic vessels with wine, olive oil and grains. The Old Oligarch ratified the activity in V sec mentioning that the Athenians, by the maritime domain, mingled with other ethnicities and discovered various consumer products ... whatever the product and wherever it may be, Sicily, Italy, Cyprus, Egypt, Lydia, and the Sea Black all comes to the same point of the Port of Piraeus by virtue of naval power (Const. of Athens, II: 07). The quotation from the Old Oligarch shows that Athens effectively exercised thalassocracy and unipolar leadership in the Aegean Sea, and that the Greeks were aware of the existence and access to the Black Sea. Daniela Dueck states that the Greeks were already in the process of expansion in the Mediterranean in the archaic period due to the dominance of the navigation by the slopes and the knowledge of bordering regions. However, in the seventh century, the Greeks venture towards the Black Sea (Dueck, 2012: 2).

The network in the ancient Mediterranean and the maritime domain requires nautical knowledge, and expertise in astronomy to be sure about the direction, and the Greeks had knowledge of the imaginary representation of the world known. The fragment DK12A1 of Diogenes de Laertes quotes that Anaximander of Miletus had been considered as the first logographer to use a gnomon among the Hellenes, knowledge learned from his stay in Egypt and Babylon (Herodotus, II: 109). The instrument allowed Anaximander to mark the circumference of the earth, defined the solstices and equinoxes, demarcated the division of the day into 12 parts and traced a contour of land and sea (Kirk, 1994: 99).

The instrument boosted knowledge about geography and remained in the memory of the Greeks, as the geographer Agathemerus, a contemporary of Strabo, points out to us:

Anaximander of Miletus, the disciple of Thales, was the first one who dared to draw the inhabited world / oikoumenes on a board; after him, Hecateus of Miletus, a well-travelled man, perfected the map, so that the work became a source of admiration (Agathemerus, I, 1 apud Kirk, 1994: 103).

The citation mentions the geographer Hecateus of Miletus as one who perfected the map of the inhabited world/oikumenes. The researcher Katzuso Koike considers that Hecateu of Miletus, a connoisseur of the old poetic culture, had full notion that many of the geographic data provided 
by Homer had some veracity. He states that Hecateu of Miletus could travel on his own way and to verify whether epic Homeric information was credible or not. While on the one hand, it was practically impossible to locate the islands of Circe and Calypso, or the land of the Cyclopes and the Lótophagos. They were in full compliance with the epic intentions of Ulysses' voyage, on the other hand, many cultural and anthropological aspects served as a basis for the periplus description of Hecateu of Miletus. For example, the author of the Odyssey reports that the Cyclops were basically rude shepherds, who lived on fertile lands but did not

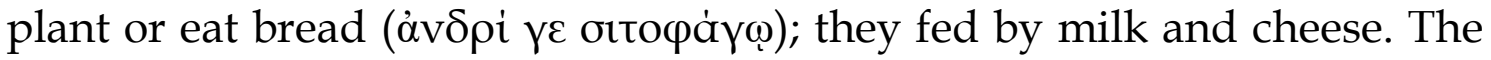
Cyclops has several marks of savagery and lack of culture, which the poet aligns. For example, The Cyclops was large, had big one-eyed, and looking giants with bib force, who lived without making laws and practicing agriculture (Odyssey, IX 292- 293). He had no cities, and no built boats and practiced anthropophagy (Katzuso, 2013: 81).

Koike confirms that Hecateu will make the descriptions of many regions and will further report that the Egyptians were bread-eaters, considering that word artos is the common term for bread in ancient Greek. However, Hecateu mentions that the inhabitants of Gérasa, the city of Libya, are bread-eaters, the term used is sitóphagoi, the same that appears in Homer, a compound word that uses as root, wheat, flour, grain or bread to name those who live on what they plant, in this case, grains (Katzuso, 2013: 82).

Herodotus in the classical period, undertakes sea voyages around the inhabited world/oikoumenos, through an anthropological approach, brings us the specificity of some cultures, like those mentioned by Homer and Hecateu, let us see the quote:

Androphagos have the wildest customs among all men, for they do not observe justice and do not adopt any law. They are nomadic and dress in the manner of dating, have a language of their own, and among all peoples are the only ones to eat human flesh. (Herodotus, IV, 106)

Then Herodotus, in his maritime periegesis around the world, mentions the encounter with the culture of the Lotóphagos of the Libyan coast, the quotation:

There is a point of land penetrating by the sea before the territory of the gindanes, in it inhabit the lotóphagos that live eating the fruit of the lotus exclusively. These fruits are the size of the berry, and have a sweet taste like that of the dates, and the lotóphagos also make wine of these fruits (Herodotus, IV, 177). 
Herodotus confirms his maritime voyage by mentioning that the peoples enumerated above are the nomadic Libyans living on the seafront (Herodotus, IV, 181). The quotations from the "father of history" allow us to affirm that his book Historia/ investigation, in the first half of the fifth century, shows that it transited through different inhabited regions. Traveling to strange and exotic worlds, he sharpened his power of observation over the area, leading him to venture into the demarcation of a geographical map, like those built by the Ionian tradition. It is interesting to note that Herodotus criticized the fact that geographers such as Anaximander and Hecateu of Miletus, from a trading city and founder of colonies, had traced the Asian continent in the same proportion as the region of Europe, let us see the quote:

I smile to see that so far many have drawn the circuit of the Earth ... without any of them have given the subject a reasonable explanation represents the Ocean to run around the earth and draw with compass/gnomon what result to make Asia equal to Europe (Herodotus, IV: 36).

In the map of Anaximander of Miletus, it is well demarcated that the centre of the civilized world in the archaic period was around the river Nile, considered the region as the cradle of humanity and that the Egyptians bequeathed the Greeks' alphabet and the gnomon (Couprie, 2003: 50). The Greeks were already familiar with the highly and complexity of the knowledge of ancient Near Eastern cultures. They knew their position in the archaic world was occupied a peripheral position (Malkin, 2011: 8). On the map of Anaximander of Miletus, showed there was also the Black Sea and this region was called the Euxine Sea/god sea for foreigners, and the Phasis river in Colchis was demarcated. This information indicated that the area of Black Sea was known to the Greeks in the archaic period.

Another fact that strikes us is the division of the Orbis terrarium, the inhabited world / oikoumenos composed of Europe, Asia and Libya indicating possible migrations of different ethnicities; some would be familiar to Anaximander from observations and travel. It is noted that the location of each ethnic group maintains demarcation on the map as well as migration routes, trading areas and military settlements of Greek warriors (Couprie, 2003: 52). Herodotus seems to have analysed the map of the inhabited world from Miletus in criticizing those who separated and divided the inhabited world into three parts, namely:

I admire, then, those who separated and divided the world among Libya, Asia, and Europe; in fact, the difference between these three parts is not small, for in the longitudinal sense Europe stretches along the two other parts together, and its breadth seems to me incomparably greater. In fact, our knowledge of Libya 
shows that the sea surrounds it, except for its borders with Asia (Herodotus, IV:42).

Using the gnomon, the pre-Socratic promoted a revolutionary process of geographical abstraction representing the space of the Mediterranean in which it included the Black Sea. The delimitation of the regions by the cartography of Anaximander established an innovative way of seeing the world, perhaps to materialize the mythical navigations sung in the epic poems of the aedos and rhapsodic, narrators of Homer, who travelled through the region of the maritime space known by the Greeks.

The first writing of Hecateu, according to Katzuso Koike, ends in the production of a travel literature that developed in the Greek world because of the Ionian colonization in the Mediterranean and by the confirmation of the use of the own writing like the technique of intellectual production. The journals, as thematic in Greek literature, were part of several genres, such as the epic of the Iliad and Odyssey, as well as geographical or historical narratives, such as Herodotus and later, Pausanias. Men travelled from the sixth century BC, such as Eutheria of Massalia, Cílax de Carianda and Hecateu of Miletus themselves, recorded their explorations in writings known in Greek as Périploi and Periegesis (Katzuso, 2013, 125). The Greek verb peripléo means to sail around or circumnavigate, expresses the meaning and the description of a maritime itinerary, in which the geographer provided geographical information of paths travelled, as well as the distances, the location of ports, apoikias, ethnic groups and points of reference for nautical travellers.

The period gês contains the earliest idea of representation of the inhabited and known earth, then made on a pinax, like the maps constructed by Anaximander and Hecateu of Miletus. It should remember that the Greek period was also the name given by Herodotus to the maps of the "Ions" (Herodotus, IV, 36). The expression later came to indicate a work that described these maps in detail, as we see in the fragments of Hecateu. It was by using the concept of periods that Aristotle referred to travel works, useful to rulers for treating the "customs of peoples" (Rhetoric, 1360a). The use of the term period gês in Hecateu should specifically portray his geographical chart. The name Periegesis seems to be late, there are no records of the utilization of this word in time before Polemon of Ílion, from the III-II century BC. Koike considers that Hecateu may have been the first to make a geo-ethnographic description of oikumene, and especially with Herodotus, the concept came into being closely linked to the historical genre (Katzuso, 2013: 126). 
We considered that to name the place traveled meant above all, to take possession of this space through the word. These geographers and navigators have called the maritime geographical areas where they have recently passed, for the names of the seas are not in the epic poems of the Iliad and the Odyssey, a fact which shows that they sailed by unnamed seas and little known. About Hecateu of Miletus, everything happened, differently, the fragments of the work that came to us, provide indications that the idea of assigning names to the maritime geographical spaces. It was part of the construction of recognition of the places navigated aiming at the elaboration of the relative map to the inhabited world/oikumene. For the Ionian geographers, the Mediterranean was an enclosed sea, and at the end of navigation, it was possible to find the Black Sea (Gras, 1998: 33)

We can ratify the knowledge of the Greeks on the Black Sea through the quote from Herodotus who shows that he was not in the region by citing that the area of Euxine Point is of all regions whose population is most ignorant. In fact, we can not mention any of the peoples inhabiting the interior of the Point by their knowledge, and we know no cultured man born there (Herodotus, IV: 46). However, the historian mentions that there were corns in the region, whose territory stretched as far as the North Sea in which the river Phasis (Herodotus, IV, 37). The Ions people undertook the process of migration to the Black Sea region in the VII century. They founded several poleis, apoikiai, and emporia, widely informated by Anaximenes of Lampsaco (380-320 BC), who provided a list of names of the Milesians colonies situated in the Black Sea (Gras, 1998: 59).

The geographers knew the region as Euxine Point, which we can define it with the hospitable sea, but in the period of the Argonauts was known as inhospitable place / axenos, due to the storms and the attacks of the population considered violent and wild. The social imagery of the wilderness remained for a long time, for Strabo mentions that the inhabitants of the Black Sea immolated foreigners to the gods, fed on their flesh and used the skulls of the victims of a cup (Strabo, VII, 3). Even in the face of the difficulties the Greeks brought in the region, the Milesians controlled the area because of the abundance of fish, wheat, furs, and metals. The poleis of Trapezona and Sinope have the oldest founding date, which secondly, the documentation dates back to 756 BC (Gras, 1998: 63).

The contemporary of Herodotus, the poet Euripides, mentions that Medea comes from the region of Colchis, Black Sea area, but also does not specify from which barbarian polis the princess of Colchis would come 
because the region was composed of Greek emporium and apoikias. This fact helps us to bring to the foreground the region of Colchis, a region considered by the Greeks as a member of the Barbarian poleis, but an area of interest because the region has an abundance of fertile lands, wood, grains, and gold. The process of Attic migration to the field of the Colquida located in the Black Sea in the classic period was narrated by Heródotus when mentioning the cultural contact and the geography of the region whose economic value centred around the river Phasis (Herodotus, III: 93). Pericles sailed several times through the area with a naval fleet from 437 / 36a.C. to ratify the commercial and economic connectivity of the Athens region with the commercial establishments established with the Colchis (Plutarch, Pericles: 24). Xenofontes in the work Anabasis (IV, 8.22) gives us data about the urbanization around the Black Sea, of his stay in the region that after a long journey through the mountains. He and the troops arrive at Trapezona, a colony of Sinope in the territory of Colchis. Xenophon informs us that he remained in the region of the colonies for thirty days and that participated in the athletic games of the region. At the end of the stay, there was a ritual of hospitality with present exchanges, where a relationship of philia with groups of Attic and Colchis families settled in the region was established (M.Faudot, 2005: p.108).

We consider that the materiality of information about of Colchis to the in Athenians occurred through Euripides. He brought the memory of the Athenians and other Greeks to the mythical narrative of the Golden Fleece ratified by the image in ceramics artisans and between the lines of dramaturgy entitled Medea, represented in the Theater of Dionysus in 431 BC. The mythical narrative brings the protagonist as a foreign woman from the Barbarian region of Colchis; she migrated to Greece introduced by the hands of the young Argonaut Jason.

According to Anna M. Ckonia, the presence of gold in the region has been considered as one of the driving forces that propelled the process of navigation and migration of the Attic Greeks to the area of Colchis. The region was known in antiquity as a "gold-rich region," and in modern times it became known as the "classical land of gold" in which the mythical narrative of Jason and the Golden Fleece symbolized the gold richness and the attic interest in the region (Ckonia, 2002: 263). However, T.S. Noonan brought the prospect of exports of grain from the Black Sea to Greece, mentioned by the ancient documentation, by considering the region as "Athens barn" (Noonan, 1973: 231). David Braund believes that the Piraeus Port became in the classical period an area of marked power 
and wealth due to the intense commerce and commercial exchanges with the Black Sea (Brau, 2007: 42).

We consider that the idea of Mediterranean was a construction that became synonymous with the performance of Greeks and Romans and the base of analysis for the formation of Eurocentric cultural and the imperialism. The Historiography based on Herodotus and Euripides defined that civility circulated the Mediterranean Sea and barbarism belonged to the residents of the Black Sea. The closer you are to the Mediterranean Sea, the closer you are to civility and culture, the farther and farther you walk towards the periphery of barbarian peoples, a geographical space to which contact and circulation have to be avoided. Kostas Vlassopoulos says that the relationship between Greeks and barbarians is part of a broad debate that starts from the geographical distinction between the West and the East. The Greeks held the Hellenicity, the culture, the sociability and became the reference in the West, invented democracy, freedom of expression, science, philosophy and dramaturgy and the East happened to be the area of peoples considered barbarians. (Vlassopoulos, 2013: 02).

Nowadays we are living the binary relation of opposition between West and East, Christian versus Muslims and Europeans versus barbarians. However, in the intellectual field and academic universe, the members of Soviet Classical Studies maintain publications in the English language. The editions of the work Ruthenia Classica Aetatis-----Novae: A Collections of World by Russian scholars in Ancient Greek and Roman History (2013). Emerges approaches by holding congresses in which present the current state of issues related to the Black Sea region as 6th International Congress on Black Sea Antiquities in Constanta, from 18 to 22/09/2017; Actes du IXe / 1999 and Xe / 2002 Vani Symposium, Colchis. There is the group of Anglo-American researchers, in partnership with Russian Hellenists and scholars from universities in the Black Sea that carried out the series of online publications entitled: International Center for Black Sea Studies. There is The Greek on the Black Sea: Ancient Art from the Hermitage and The British Institute at Ankara responsible for archaeological research in the region of Turkey and the Pichvnari region in the Black Sea. We can say that we know the Aegean well, the researchers debated on the question of the Mediterranean and the relationship with the population based on its margin, and now we are sailing in the turbulent and stormy waters of knowledge towards the Black Sea. For us, Hellenists and researchers, connectivity and knowledge about the maritime geographical space in the Euxine Point region and the region of Colchis permit one full navigation. 


\section{Ancient Sources}

ARISTOPHANES. The Plays of Aristophanes. William Benton Publisher. London: Encyclopedia Britannica, 1952. Ed. bilíngue.

ARISTOTLE. Constitution d'Athènes. Trad. G. Mathie. Paris: Les Belles Lettres,1996.

Politics. Trad. H. Rackham. Cambridge: The Loeb Classical

Library, 1990. Ed. bilíngue.

HERODOTUS. History. Trad. A. D. Godley. London: Willian Heinemann, vol.1 (1990), vol. 2 (1995), vol. 3 (1994), vol. 4 (1981) - Ed. bilíngue.

PAUSANIAS. Description of Greece. Books I and II. Trad. W. H. S. Jones. Cambridge: Harvard University Press, 1992.

PLUTARCH. Biography. Bernadotte Perrin. Harvard University Press, 1989.

STRABON. Geographie. Tomes VI. Trad. Raoul Baladié. Paris: Les Belles Lettres, 1978.

THÉOPHRASTE. Characters. Paris: Les Belles Lettres, 1964.

THUCYDIDES. History of the Peloponnesian War. London: William Heinema. Vol. 1 (1991); vol. 2 (1998); vol. 3 (1992); vol. 4 (1976). Ed. bilíngue.

XENOPHON. Hellenica. London: William Heinemann,vol.1 /2, 1985.

Memorabilia, Oeconomicus. London: William Heinemann, 1992

Anabasis IV. Trans.Carleton L. Brownson.London: The Loeb Classical Library,1930.

\section{Bibliografic References}

ANDREAU, Jean. “L'économie antique: présentation”. Annales, 5, 1995, p. 947-960.

BERARD, Claude et ali. A City of Image: iconography and society in ancient Greece. Princeton: Princeton University Press, 1989. 
BOARDMAN, John. Greek Sculture: The Classical Period. London: Thames and Hudson, 1985.

BOTHMER, Dietrich von. Painted Greek Vases. The Metropolitan Museum of Art Bulletin, vol. 21, 1962. www.jstor.org/stable3258463 acesso em 23/11/2013.

BURSTEIN, Stanley M. The Greek Cities of the Black Sea. In: A Companion to the Classical Greek World. Oxford: Blackwell,2006, p.137152.

CANDIDO, Maria Regina. Atenas, liderança unipolar no Mar Egeu (480411 ${ }^{\text {a }}$ C). Rio de Janeiro: Letras e Versos/ NEA-UERJ, 2016.

CANDIDO, Maria Regina. Medeia, Mito e Magia: A imagem através do tempo. $2^{\mathrm{a}}$ ed. Rio de Janeiro: Fabrica de Livros/NEA/UERJ, 2010.

CANDIDO, Maria Regina. Novas Perspectivas sobre aplicação metodológica em História Antiga. IN: Busca do Antigo. ROSA, Claudia Beltrão (eds). Rio de Janeiro: NAU, 2010, pp.13-23.

CARPENTER, Thomas H. T. Art and Myth in Ancient Greece. London: Thames and Hudson, 1985.

CKONIA,A.M. A propos de I'exportation de l'or colchidien. Pont-Euxin et Polis? Polis hellenis et Polis Barbaron. Comtoises: Presses Université Franche-Comtoises,2005, p.263-272.

COHEN, Beth. Not the Classical Ideal: Athens and Construction of the Other in Greek Art. Leiden: Brill, 2000.

CONSTANTAKOPOLOU, C.: The Dance of the Islands: Insularity, Networks, the Athenian Empire and the Aegean World. Oxford: Routledge. 2007.

COUPRIE, Dirk L.(org.) Anaximander in Context: new studies in origins of Greek Philosophy. New York: New York University Press, 2003.

COUPRIE, Dirk L. Heaven and Earth in Ancient Greek Cosmology: from Thales to Heraclides Ponticus. New York: Springer, 2011.

DANA, Madalina." Le Centre et la peripherie en question:deux concepts a revoir pour les disaporas", Pallas, 89, 2012mpp.57-76.

DIGGLE, James. On the Manuscripts and text of Eurípides: Medea. In: Classical Quarterly 33, p.339-357,Oxford: Oxford University Press,1983. 
DOUMAS, C. What Didi the Argonauts seek in Colchis? Hermathena $\mathrm{n}^{\circ} 150$. Dublin: Trinity CollegeDublin, 1991.

DUECK, Daniela. Geography in Classical Antiguity. Cambridge: Cambridge University Press,2012.

FIGUEIRA, Thomas. Colonization in the Classical Period. Mnemosyne, Vol. II, Supplement 193, Leiden:Brill, 2008, pp.427-522.

FAUDOT, M.(eds). Pont-Euxin et Polis? Polis hellenis et Polis Barbaron. Comtoises: Presses Université Franche-Comtoises,2005.

FINLEY, Moses I. "The ancient city: from Fustel de Coulanges to Max Weber and beyond", in FINLEY, M. I. Economy and society in ancient Greece. Edited by Brent D. Shaw \& Richard P. Saller. Nova Iorque: Penguin Books, 1983, p. 3-23.

FINLEY, Moses. I. A Economia Antiga. Porto: Afrontamento, 1986.

GABRIELSEN,Vicent. The Black Sea in Antiguity. Oakville:Arhus University Press,2007.

GILL,David W. J.Positivism, pots and long-distance trade. In: MORRIS, Ian (ed). Classical Greece: Ancient Histories and Modern Archaeologies. Cambridge: Cambridge University Press, 1994, pp.99-107.

HANSEN, Morgens Herman. Emporium:a study of the use and meaning of the term in the archaic and classical periods. In: Greek colonization:an account of Greek colonies and other settlements overseas. Leiden: Brill, 2006,p.1-39.

HOPMAN, Marianne. Revenge and Mythopoiesis in Euripides'Medea. In: Transactions of the American Philological Associations, 138 (2008)p.155183.

JOHNSTON,Sarah Iles. Medeia: essay on Medea in myth, literature, philosophy and art. Princeton: Princeton University Press, 1997.

KAKHIDZE, A., IASHVILI. I., Vickers, M. "Silver coins of Black Sea coastal cities from the fifth century BC necropolis at Pichvnari". Numismatic Chronicle 161, 2001, pp.282-288

KVIRKVELIA, Guram. Polis Barbaron in the Black Sea area in archaic and classical periods. Pont-Euxin et Polis?Polis hellenis et Polis Barbaron. Comtoises: Presses Université Franche-Comtoises,2005, p.33-40. 
LUSCHIMIG,C.A.E. Granddaugher of Sun: A study of Euripides'Medea. Leiden: Brill, 2007.

MCDERMONTT, Emily A. Euripides'Medea: The Incarnation of Disorder. Pennylvania: The Pennsylvania State University Press,1989.

MEHL,Andreas (eds) Ruthenia Classica Aetatis Novae: A Collections of Words by Russian Scholars in Ancient Greek and Roman History. Stuttgart: Franz Steiner Verlag, 2013.

NOOMAN,Thomas S. The Grain Trade of the Northern Black Sea in Antiguity. The American Journal of Philosophy.vol.94, no 03, 1993, pp. 231-242.http:// www.jstor.org. acessado em 10/02/2016.

NORA P. "História e Memória. Projeto História, Revista de Programa de Estudos Pós-Graduação em História e do Departamento de História da PUC-SP. São Paulo: PUCSP, 1981, p. 7-28.

PEBARTHE,Christophe. Emigres d'Athenes, Clerouques et Colons aux temps de la Domination Athenienne sur L'Egeu au V siecles a.C. in: Le Monde de L'Itinerance en Mediterranée de L'Antiquitw a L' Epoque Moderne. Paris:DE Boccard, 2009, pp.367-390.

ROBERTSON, Martin. The Art of vase-painting in Classical Athens. Cambridge: Cambridge University Press,2000.

ROLLER, Duane W. Erastothenes' Geography. Princeton: Princeton University Press,2010.

TROFINOVA, Anna et J.Paul Getty Museum. Greek on the Black Sea: Ancient Art from the Hermitage. Los Angeles: Getty Publications, 2007.

TSETSKHLDZE, Gocha. Pichonari and its environs. Paris: Universitaires Franc-Camtoise, 1999.

TSETSKHLDZE, Gocha. Greek Penetration of the Black Sea. In: The Archaeology of Greek Colonization. Oxford: Oxford University Press,2004, p.111-131.

VELHO OLIGARCA. A Constituição dos Atenienses. Trad. Neyde Theml e André Chevitarese. Vitória: EDUFES, 2002.

VICKERS, M., Kakhidze, A.: 'The British-Georgian excavation at Pichvunari 1998: the 'Greek' and 'Colchian' cemeteries' Anatolian Studies 51,2001 , p. $65-90$ 
VICKERS, M., Kakhidze, A. Pichvnari 1: Greeks and Colchians on the East Coast of the Black Sea: Results of Excavations Conducted by the Joint British-Georgian Expedition 1998-2002. Batumi.2004.

VLASSOPOULOS, Kostas. Greeks and Barbarians. Cambridge: Cambridge University Press,2013.

WYGANT, Amy. Medea, Magic and Modernity in France. Hampshire: Ashdate Publishing Limited, 2007. 